\title{
Predicting The Corporate Social Responsibility Of Listed Companies In Greece Using Market Variables
}

Anastasia Maggina, Ph.D., Business Consultant/Research Scientist, Greece Angelos A. Tsaklanganos, University of Nicosia, Cyprus

\begin{abstract}
This study primarily investigates differences in the market variables of companies that show corporate social responsibility (CSR) compared with those that do not. We also examine whether predictions of CSR can be determined and which statistical technique better fits the data set. In this study, CSR is explored using dichotomous analytical techniques such as discriminant analysis and a logit specification. The results of these analyses indicate that very few of the investigated market variables—stock price, stock returns, earnings per share, and dividends—play a role in discriminating between these two categories of companies, while firm size plays almost no role at all. This study, which is limited to companies listed on the Athens Stock Exchange, has significant practical implications because it can motivate potential investors and/or the public at large to decide to invest in companies that demonstrate a high degree of CSR and improve policymaking through appropriate policies or incentives for CSR programs. This study is an original research paper that presents novel empirical findings. It adds to the body of knowledge on this topic because of its serious policy implications as well as its innovative model building and derived findings.
\end{abstract}

Keywords: Companies Corporate Social Responsibility Market Variables; Corporate Social Responsibility of Greek Companies

\section{INTRODUCTION}

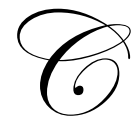

orporate social responsibility (CSR), the notion that business enterprises must be economically, ethically, and socially viable, is considered to be a modern way of doing business. It has a long experience in the US, with its roots in the pivotal 1953 decision by the New Jersey Supreme Court that removed legal restrictions on corporate philanthropy. However, it is a more recent phenomenon in Europe, even though Greece has a long tradition of public donations. For example, since the period of ancient Greece, individuals have donated funds to the state or erected public buildings.

In many European countries, there is a growing movement in favor of CSR. CSR has been backed up in the European Union by the Council Resolution of 6 February 2003 (2003/C 39/02). The Council of the EU has also recalled the Commission Green Paper on promoting a European framework for CSR, which launched a consultation procedure on the concept. The Council Resolution of 3 December 2001 on the follow-up to the Commission's Green Paper (1) recognized that CSR can contribute to reaching the objectives laid down by the European Council, namely for the EU to become the most competitive and dynamic knowledge-based economy in the world by fostering social integration and sustainable development.

The creation of shareholder wealth as an objective and a yardstick of organizational success has become overshadowed by the broader concept of success. As noted by Heslin and Ochoa (2008), approximately one in every 10 dollars of assets under management in the USA in 2006 was invested in companies that rate high on a certain CSR measure. Further, it was shown in 2007 that $64 \%$ of Fortune 100 companies publish a CSR report that describes their economic, environmental, and social performance. 
Although there are various definitions of CSR, most share the theme of engaging in economically sustainable business activities that go beyond legal requirements in order to protect the well-being of employees, communities, and the environment. McWilliams and Siegel (2001) defined CSR as "actions that appear to further some social good, beyond the interests of the firm and that which is required by law." In the international arena, CSR include actions such as making extensive charitable contributions, promoting community development plans, maintaining plants in economically depressed locations, and establishing environmental protection procedures. According to Tsaklanganos (1976), other areas of social responsibility include the following:

- $\quad$ Small and minority-owned firms that can be developed with the help of big business through monetary assistance, managerial training, and technical guidance;

- Educational functions in the community such as (i) providing financial support to schools for equipment, libraries, and construction, (ii) donating supplies or labor, and (iii) allowing the use of office facilities in the evening for college and community educational programs; and

- The renewal of cities by building or renovating middle- and low-cost housing, helping improve transportation facilities, and upgrading other municipal services.

CSR is considered to be a key driver for engaging the wider community as an important stakeholder in business activity. Heal (2004) defined CSR as a program of actions taken to reduce externalized costs or to avoid distributional conflicts. Further, according to Heal (2004), CSR has evolved in response to market failures. According to Nelling and Webb (2009), CSR includes supporting local businesses or charities, developing recycling programs, and promoting minority employment.

According to an Awareness and Social Behavior Index that is used in Greece (MEDA Communication SA, 2009), $40 \%$ of consumers know about the existence of companies that demonstrate CSR. Further, eight out of 10 employees in the private and public sector agree that CSR is very important to social life and 35\% of citizens believe that companies use CSR to improve their images. However, $65 \%$ of employees do not know whether the business enterprise in which they work demonstrates CSR.

CSR has been established in the corporate governance frameworks of Greek companies listed on the Athens Stock Exchange (ASE). For example, for the first time in Greece, a company has been awarded a prize for CSR (the Bank of Piraeus was recognized by the Greek Chamber of Commerce and Industry). However, the present study shows that the rate of Greek-listed companies that have CSR remains low (only 8.6\% (24 of 279) of companies that report financial statements on the website of the ASE and 8.9\% (24 of 270) of the sample companies in this study). This is based on companies that provide information in two consecutive years on at least one of the four market variables selected in this study: stock price, stock returns, earnings per share (EPS), or dividends.

CSR has been considered in the frameworks of firm performance and less in those of capital markets, yielding mixed results in the international literature. Thus, this study examines the effect of market variables on the discrimination between companies that have CSR and those that do not and investigates whether CSR can be forecasted. The motivation behind the study was the growing number of (both private and public) companies that have CSR. Its research objectives are threefold:

- $\quad$ To highlight the differences in market variables between companies that have CSR and those that do not;

- To test the predictability of CSR; and

- $\quad$ To check which statistical technique better fits the data set.

The remainder of the paper is organized as follows. Section II reviews the literature. Section III contains the research design. Section IV reports the empirical findings. Section V concludes with a summary and suggestions for further future research.

\section{REVIEW OF THE LITERATURE}

Even though CSR is a traditional business discipline, it has been studied only sporadically. Research studies are dispersed over a long time horizon and academic research has examined the causal relation between CSR and financial performance (sometimes referred to as the "virtuous circle"). 
CSR has its origins in community issues. As far back as 1946, Demming argued that "statistical quality techniques ought not to be limited to economic applications" (Juran, 1994). He argued for the significance that would emerge from social contributions through the application of quality tools and techniques. Demming's views were further stressed by Juran (1994), who has often argued in favor of quality institutions expanding their mandates by placing more emphasis on providing services to society.

Although social issues have been debated for centuries, only recently have they joined the mainstream management literature as a legitimate area of inquiry. Levy (1999) claimed that corporate philanthropy and social initiatives are the "heart and soul" of business. He stressed that "social endeavors must be consistent with business objectives for earning profit (heart) and must express the values of serving society (soul)."

Further, certain firms have responded to these concerns by devoting more resources to CSR in order to gain competitive advantage. According to Lin et al. (2009), CSR can be a proactive business strategy and an effective marketing tool to create and sustain a competitive advantage. However, some top management teams have resisted, arguing that additional CSR investment is inconsistent with efforts to maximize profits. This disagreement has prompted researchers to examine the relationship between CSR and financial performance in an effort to assess the validity of these concerns.

The management literature has acknowledged that social responsibility is an important corporate duty (Tsaklanganos, 1974; 1976; Quinn et al., 1987; McGuire et al., 1988). As Carrington (1970) stated, a healthy business system cannot exist in a sick society. Tsaklanganos (1976) argued that business must also participate in solving the community and societal problems at large. According to Arlow and Gannon (1982), Ullmann (1985), and McGuire et al. (1988), CSR is significant in corporate decision making because of the relationship between a firm's social policies or actions and its financial performance.

The main body of research on this topic has thus focused this relationship between a firm's social responsibility and its financial performance from three standpoints. The first is that firms face a trade-off between social responsibility and financial performance. Proponents of this viewpoint argue that firms incur costs from socially responsible actions, which thereby places them at an economic disadvantage compared with other less responsible firms (Aupperle et al., 1985; Ullmann, 1985; Vance, 1975). The second standpoint is that the explicit costs of CSR are minimal and that firms may actually benefit from social responsible actions in terms of employee morale and productivity (Moskowitz, 1972; Parker and Eilbirt, 1975). Finally, the third standpoint believes that the costs incurred by socially responsible actions, although significant, are offset by a reduction in other costs.

According to stakeholder theory (Cornell and Shapiro, 1987), apart from stockholders and bondholders, those with less explicit claims should be satisfied. Alexander and Buchholz (1978) and Bowman and Haire (1975) asserted that stakeholders may see CSR as indicating management skill. For example, an increase in perceived social responsibility may improve the image of the firm's management and permit it to exchange costly explicit claims for less costly implicit charges. If a firm does not act in a socially responsible manner, however, the parties of implicit contracts concerning the social responsibility of the firm may attempt to pursue the costly decision to transform such agreements. Firms that display a high degree of CSR may find that they have more low-cost implicit claims compared with other firms and thus have higher financial performance (Cornell and Shapiro, 1987).

Research into the relationship between CSR and financial performance has been developed from certain theoretical arguments. On one hand, supporters of the negative relation between social responsibility and financial performance argue that high responsibility results in additional costs (Bragdon and Marlin, 1985; Vance, 1985). On the other hand, those who argue for a positive association cite improved employee satisfaction and customer goodwill as an important outcome of social responsibility (Davis, 1975).

Socially responsible activities may also improve a firm's standing in the eyes of external stakeholders such as bankers, suppliers, creditors, investors, and government officials, which may bring about economic benefits (Moussavi and Evans, 1986). According to Spicer (1978), bankers and other institutional investors value social considerations in their investment decisions. Thus, high CSR may improve a firm's access to sources of capital. 
Some scholars have also argued for a relationship between social responsibility and such measures of financial risk as variance in earnings and in stock returns (Spicer, 1978; Ullmann, 1985). Low levels of social responsibility may increase a firm's financial risk. Investors may consider less socially responsible firms to be riskier investments because they see management skills at the firm as low (Alexander and Buchholz, 1978; Spicer, 1978). In contrast, a high degree of CSR may permit a firm to have relatively low financial risk as the result of more stable relations with the government and financial community. Further, high-CSR firms may also have a low percentage of total debt to total assets, which helps companies satisfy implicit claims.

CSR may also be linked to past firm performance, which may influence a firm's evolving social policy and actions (Ullmann, 1985). If CSR is viewed as a significant cost, firms that display relatively better past financial performance may be more willing to absorb these costs in the future (Parker and Eilbirt, 1975; Ullmann, 1985). In contrast, less profitable firms may be less willing to undertake socially responsible actions.

However, it is important to note that previous empirical research on the relationships between CSR and measures of firm performance has yielded mixed results. Moskowitz (1972) reported that high-CSR firms have higher than average stock returns. Later, however, Vance (1975) found that a subset of the firms rated by Moskowitz had lower stock market performance compared with a sample of firms listed on the NYSE Composite Index, Dow Jones Industrials, and S\&P Industrials. Meanwhile, Alexander and Buchholz (1978) adjusted the risk measures for stock returns in order to show that the relationship between social responsibility and market performance is very low.

Bragdon and Marlin (1972), Bowman and Haire (1975), and Parker and Eilbirt (1975) all reported a positive association between CSR and accounting-based measures of performance. Cochran and Wood (1984) also found a positive correlation between social responsibility and accounting performance after controlling for the age of assets. In contrast, Aupperle et al. (1985) found no significant relationships between social responsibility and a firm's return on assets adjusted by its ranking in the Value Line Safety Index. Sturdivant and Ginter (1977), by categorizing firms as best, honorably mentioned, and worst in terms of social responsibility, found that firms with an honorable mention had higher accounting-based performance than did the other firms. Finally, McGuire et al. (1988) found that low-CSR firms experience lower returns on assets and stock market returns than do firms high in social responsibility. They further showed that prior performance is generally a better predictor of CSR than is subsequent performance.

Mele (2004) argued that Spanish companies consider corporate reputation, competitive advantage, and current industry trends to be the major driving forces for CSR and that these factors are closely related to certain cultural, social, and political influences. Heal (2004) asserted that CSR is an important part of corporate strategy in sectors where inconsistencies arise between corporate profits and social goals, or discord can arise over fairness issues. He argued that the growth of socially responsible investing suggests there may be a connection between a firm's policies towards CSR and its position in capital markets. Moreover, CSR programs allocate resources in cases of market failure through private social cost differentials and when distributional disagreements are likely to be strong. Finally, a CSR program can be a profitable element of corporate strategy, contributing to risk management and to the maintenance of relationships that are important to long-term profitability.

Morrison Paul and Siegel (2006) described some perspectives on CSR in order to provide a context for considering the strategic motivations and implications of CSR. These authors also called for further theoretical and empirical research into CSR.

Heslin and Ochoa (2008) classified a range of strategic CSR undertakings into seven principles: cultivate needed talent, develop new markets, protect labor welfare, reduce environmental footprint, profit from by-products, involve customers, and green your supply chain. They stressed that these principles could serve as a guiding stimulus for other organizations intent on discovering and capitalizing on their unique opportunities to do well by doing good. Engaging in strategic CSR, they argued, can grow market share, increase organizational learning, retain deeply engaged employees, generate support from external shareholders, and improve relationships with investors. 
Lin et al. (2009) examined 1000 Taiwanese cases in which firms classify R\&D expenditure as a business strategy for sustainable development and charitable donations as a contribution to CSR. Based on theoretical assertions and empirical evidence, these authors identified a positive relationship between CSR and financial performance. They further found that although CSR has little positive impact on short-term financial performance, it offers a remarkable long-term fiscal advantage.

Nelling and Webb (2009) used a time-series fixed effects approach to demonstrate that the relation between CSR and financial performance is weaker than previously thought following traditional statistical analysis. Their results suggested that strong stock market performance leads to greater firm investment in aspects of CSR devoted to employee relations, but that CSR activities do not affect financial performance.

Recently, Sikka (2010) dealt with organized tax avoidance by companies that demonstrate CSR in the sense that organizational culture and practices have not necessarily been aligned with publicly espoused claims for responsible and ethical conduct (what the author termed "organized hypocrisy").

\section{RESEARCH DESIGN}

\section{Research Method}

This study employs both discriminant analysis and logistic regression. These statistical methods offer different perspectives on the ability of a set of descriptive variables (our market variables) to predict whether a firm has the feature of research interest (our binary response variable). The feature variable defines two outcome categories or classes. Companies with corporate social responsibility take the categorical value 1 and companies with no corporate social responsibility take the categorical value 0 . The aim of both methods is not only prediction but also explanation. The methods give insights into which descriptive variables are central to successful classification of firms into the two categories.

We denote the set of descriptive variables by a vector $\mathrm{x}=\left(1, \mathrm{x} \_1, \ldots, \mathrm{x} \_\mathrm{k}\right)$, where component 1 is included to allow an intercept or constant term in our analysis. We denote the binary $(0,1)$ response variable by $y$, with $y=1$ representing a firm with the feature of interest and $y=0$, a firm without it. Discriminant analysis and logistics regression differ mainly in the direction of their statistical inference. In logistic regression, the research question is "What is the probability that $\mathrm{y}=1$ when the firm has descriptive vector $\mathrm{x}$ ?" In mathematical terms, logistic regression is concerned with the conditional outcome $\mathrm{y} \mid \mathrm{x}$ (that is, $\mathrm{y}$ given $\mathrm{x}$ ). In discriminant analysis, the research question is "What profile of descriptive variables $\mathrm{x}$ distinguishes a firm with $\mathrm{y}=1$ from a firm with $\mathrm{y}=0$ ?" In mathematical terms, discriminant analysis is concerned with the conditional outcome $\mathrm{x} \mid \mathrm{y}$ (that is, $\mathrm{x}$ given y). Observe the reversal of the conditional relationship. For mathematical convenience, the two methods are implemented under slightly different assumptions, as we now describe.

In logistic regression, the probability that the firm has the key feature, namely, $\mathrm{p}=\operatorname{Pr}(\mathrm{y}=1)$, is related to descriptive vector $\mathrm{x}$ by (1) a linear regression function $\mathrm{xb}$, where $\mathrm{b}$ is a column vector of regression coefficients, and (2) the logistic link function $\mathrm{p}=\exp (\mathrm{xb}) /[1+\exp (\mathrm{xb})]$. The cumulative logistic distribution function is similar to a cumulative normal distribution function but has a simpler mathematical form. The vector $\mathrm{b}$ is estimated from the data using the method of maximum likelihood. We employ SPSS, a standard statistical software package, for the results. As will be seen in the fitted logistic regression functions reported later in Section 4, the logistic regression function allows us to see which descriptive variables in vector $\mathrm{x}$ are especially important in predicting whether or not a firm has the feature $(\mathrm{y}=1)$.

The conventional model for discriminant analysis assumes that the vector of descriptive variables $\mathrm{x}$ for a firm is drawn randomly from one of two multivariate normal distributions corresponding to firms with the feature $(\mathrm{y}=1)$ and firms without the feature $(\mathrm{y}=0)$, respectively. The discriminating power of the descriptive vector $\mathrm{x}$ is determined by the extent of separation of the locations (mean positions) of the two normal distributions. The greater the distance between the means keeping other factors the same, the greater the discriminating power of the descriptive variables. A linear discriminant function $\mathrm{xd}$ is formed as a linear combination of the descriptive variables, where $\mathrm{d}$ is a column vector of the discriminant coefficients. A linear discriminant function arises 
mathematically in a setting where the covariance matrix of the two multivariate normal distributions are equal. As with logistic regression, an examination of the discriminant coefficients d tells us which descriptive variables are most important in separating the mean positions of the two multivariate normal distributions. Again, we use SPSS to do the discriminant analysis. The most challenging assumptions of the linear discriminant approach are, first, the requirement for multivariate normality and, second, the requirement for equal covariance matrices. The analysis is reasonably robust to modest departures from these assumptions. Results of this estimation procedure and an assessment of the discriminating power of the descriptive variables for our application are presented in Section 4. Our use of two statistical methods here allows the results of one approach to check the reasonableness of results from the other approach. The different perspectives offered by the methods also provide some additional research insights.

\section{Variable Selection}

The variables used in this study are three traditional market variables, namely stock price, EPS, and dividends, plus a computed market variable, namely stock returns. The latter was computed in line with Easton and Harris (1991) using the book value valuation model or earnings valuation model.

The book value valuation model indicates that

$$
P_{i j}=B V_{i j}+u_{i j}
$$

Taking first differences we have

$$
\Delta \mathrm{P}_{\mathrm{ij}}=\Delta B \mathrm{BV}_{\mathrm{ij}}+\mathrm{u}_{\mathrm{ij}}
$$

But in general

Substituting (3) into (2), rearranging, and dividing by $\mathrm{P}_{\mathrm{ij} \mathrm{j}^{-1}}$ yields:

$$
\Delta B V_{i j}=A_{i j}-d_{i j}
$$

$$
\left(\mathrm{P}_{\mathrm{ij}}+\mathrm{d}_{\mathrm{ij}}\right) / \mathrm{P}_{\mathrm{ij}{ }^{-1} 1}=\mathrm{A}_{\mathrm{ij}} / \mathrm{P}_{\mathrm{ij}{ }^{-1} 1}+\mathrm{u}_{\mathrm{ij}}
$$

In contrast,

$$
\mathrm{P}_{\mathrm{ij}}=\rho \mathrm{A}_{\mathrm{ij}}+\mathrm{u}_{\mathrm{ij}}
$$

Given the dividends irrelevance proposition, we have $\quad P_{i j}+d_{i j}=\rho A_{i j}+u_{i j}$

It follows that

$$
\left(\Delta \mathrm{P}_{\mathrm{ij}}+\mathrm{d}_{\mathrm{ij}}\right) / \mathrm{P}_{\mathrm{ij}-1}=\rho\left(\Delta \mathrm{A}_{\mathrm{ij}} / \mathrm{P}_{\mathrm{ij}-1}\right)+\mathrm{u}_{\mathrm{ij}}
$$

where $P_{i, j}=$ stock price (per share) of firm $i$ in period $j . A_{i, j}=$ EPS of firm $i$ in period $j . d_{i, j}=$ dividend per share of firm $\mathrm{i}$ in period $\mathrm{j} . \mathrm{a}=\mathrm{a}$ constant in a linear relationship (intercept parameter) $\mathrm{b}_{1}, \mathrm{~b}_{2}=\mathrm{a}$ slope parameter or a coefficient in a linear regression. $\mathrm{i}=$ cross-selection item, and $\mathrm{j}=$ time-series item.

\section{Sample Selection}

Companies listed on the ASE were selected for investigation in this study. The size of the sample was based on the number of firms that were displayed on the ASE website for one and two years before the event of CSR, commencing with the most recently published data in 2008. The total number of companies that reported financial statements published and found on the ASE website in 2008 was 280. A total of 270 companies satisfied the presumption of two consecutive years before the event of CSR, while 24 companies demonstrated CSR according to the ASE website and the final sample.

Thus, 24 companies certified in their annual reports that they adhere to CSR policies. These firms were dispersed across several industries (number in brackets): Food (3), Construction (3), Banks (3), Consumer Goods (2), Construction Materials (2), Pharmaceutical Companies (1), Machinery of Industrial Equipment (1), Electrical Equipment (1), Telecommunications Equipment (1), Agriculture and Fishery (1), Financial Services (1), Transportation Services (1), Lottery (1), Computer Materials (1), Clothes and Accessories (1), and Commerce (1). According to ASE industrial classifications, the analysis of the sample was as follows: 
Food and Beverage $\quad 22$

Construction $\quad 16$

Clothes and Accessories $\quad 14$

Banks 14

Real Estate $\quad 11$

Media - Publications $\quad 11$

Construction Materials $\quad 10$

Agriculture and Fishery $\quad 9$

Raw Materials - Steel 8

Specialized Retail Commerce $\quad 8$

Computer Services 9

Consumer Products $\quad 8$

Financial Services $\quad 7$

Medical Services $\quad 7$

Packing 6

Specialized Chemicals 6

Travel and Tourism 5

Machinery of Industrial Equipment 5

Commerce 5

Investment Companies 4

Personal Care 4

Raw Materials - Aluminum 4

Hotels 4

Technology - Software 4

Support Services to Companies 4

Insurance 4

TV and Entertainment 4

Furniture 3

Technology - Electrical Office Equipment 3

Petroleum 3

Industry Suppliers 3

Computer Materials 3

Lottery 3

Telecommunication Equipment 3

Transportation Services 3

The following groups of industries have one or two companies: Technology - Telecommunications Equipment (2), Commercial Cars (2), Industrial Products and Services (2), Chemicals (2), Pharmaceutical Products (2), Raw Materials - Minerals (2), Raw Materials - Non-iron Metals (2), Water Supply (2), Computers (2), Travel and Entertainment (2), Electricity (x), Internet (1), Food Retail and Wholesale Commerce (1), Media - Advertising (1), Basic Chemicals (1), Telecommunications (1), Shoes (1), Tobacco (1), Cement Companies (1), Airlines (1), Basic Commerce (1), Wood Products (1), House Equipment - Commerce (1), Personal and Household Goods (1), and Retail Commerce (1).

\section{EMPIRICAL FINDINGS}

By considering the means of each variable used in the analysis, the results illustrate the differences between the categories of companies. We find that companies with and without CSR do not present great differences, except in terms of stock price, when all data are used or when outliers are excluded. 
Table 1: Average Ratios (Means)

\begin{tabular}{lcccc}
\hline & \multicolumn{2}{c}{ All Data } & Outliers Excluded \\
& CSR & NON-CSR & CSR & NON-CSR \\
\hline Stock Price & 8.4704 & 3.7914 & 8.4704 & 3.0369 \\
Stock Returns & -0.3355 & -0.2889 & -0.3355 & -0.2889 \\
EPS & 0.6717 & 0.2594 & 0.6717 & 0.2594 \\
Dividends & 0.3356 & 0.1511 & 0.3356 & 0.1513 \\
\hline
\end{tabular}

The Kolmogorov-Smirnov test is an appropriate test of normality. It is important to test normality because outliers may have a big influence on the result. It is worth noting that the variable stock price has five outliers. Further, the number of outliers has been shown to be very small in other studies that have examined the distributional properties of financial ratios (Deakin, 1976; So, 1987; Karels and Prakash, 1987).

Table 2: Normality Test (Kolmogorov-Smirnov)

\begin{tabular}{lcccc}
\hline & \multicolumn{2}{c}{ All Data } & \multicolumn{2}{c}{ Outliers Excluded } \\
& CSR & NO CSR & CSR & NO CSR \\
\hline Stock Price & $1.290(0.072)$ & $7.757(0.000)$ & $1.290(0.072)$ & $5.100(0.000)$ \\
Stock Returns & $0.552(0.921)$ & $1.151(0.142)$ & $0.552(0.921)$ & $5.151(0.142)$ \\
EPS & $1.541(0.017)$ & $6.354(0.000)$ & $1.541(0.017)$ & $6.354(0.000)$ \\
Dividends & $1.541(0.017)$ & $7.231(0.000)$ & $1.541(0.017)$ & $7.227(0.000)$ \\
\hline
\end{tabular}

As shown in Table 2 all variables in CSR companies are not normally distributed, whereas companies without CSR are normally distributed except for the variable stock returns.

The best fitting model is selected by drawing together the empirical findings from the discriminant and logit analyses. In each year, a company is observed in one of two alternative states. The coefficients for each model and for each variable for one and two years before the event of CSR along with the whole data set are given in Table 3 .

Table 3: Regression Coefficients

\begin{tabular}{|c|c|c|c|c|}
\hline & \multicolumn{2}{|c|}{ All Data } & \multicolumn{2}{|c|}{ Outliers Excluded } \\
\hline & Discriminant & Logit & Discriminant & Logit \\
\hline Stock Price & -1.656 & -0.174 & 0.715 & 0.138 \\
\hline Stock Returns & -0.427 & -1.912 & -0.409 & -2.034 \\
\hline EPS & -0.750 & -0.457 & 0.309 & 0.496 \\
\hline Dividends & -0.209 & -0.383 & 0.151 & 0.381 \\
\hline \multicolumn{2}{|c|}{ Eigenvalue $=0.013$} & & \multicolumn{2}{|l|}{ Eigenvalue $=0.137$} \\
\hline \multicolumn{2}{|c|}{ Correlation $=0.268$} & $X^{2}=10.516$ & Correlation $=0.347$ & $X^{2}=15.405$ \\
\hline \multicolumn{2}{|c|}{ Wilk's Lamda $=0.928$} & Significance $=0.033$ & Wilk's Lamda $=0.880$ & Signif. $=0.004$ \\
\hline \multicolumn{2}{|c|}{$X^{2}=12.629$} & Wald test $=74.057$ & $X^{2}=21.557$ & Wald test $=73.544$ \\
\hline \multicolumn{2}{|c|}{ Significance $=0.013$} & & Significance $=0.000$ & \\
\hline
\end{tabular}

In both the discriminant analysis and the logit analysis, all variables contribute marginally (Table 3) except stock returns, which is the most discriminating variable even though it contributes negatively. Wilk's Lamda, which is one of the various statistics available, is used to test the significance of the discriminant function as a whole. As shown in Table 3, a significant Lamda means that the null hypothesis (that the two categories have the same mean discriminant function scores) can be rejected. Thus, we find that the model is rather discriminating. 
Once the values of the discriminant coefficients have been estimated, it is possible to calculate the discriminant scores for each observation in the sample, or any firm, and assign the observations to one of the categories based on this score. The essence of this procedure is to compare the profile of an individual firm with that of the alternative groupings. In this manner, the firm is assigned to the group that it most closely resembles.

The results offered in Table 4 justify the preference of the logit analysis over the discriminant analysis, although the two methods do not differ significantly. When all data are used, the percentage of correct classification is $89.6 \%$ with the logit model and $78.6 \%$ with discriminant analysis. When outliers are excluded, the rates are $90.1 \%$ and $79.7 \%$, respectively.

Table 4: Classification Table for Groups (Percentage Correct - Overall Index)

\begin{tabular}{ccccc}
\hline \multicolumn{3}{c}{$\begin{array}{c}\text { Discriminant } \\
\text { Analysis }\end{array}$} & \multicolumn{3}{c}{$\begin{array}{c}\text { Logit } \\
\text { Model }\end{array}$} \\
\hline $\begin{array}{c}126(81.8) \\
9(47.4)\end{array}$ & $28(18.2)$ & $10(52.6)$ & 154 & $0(100.00)$ \\
& $78.6 \%$ & & 18 & $1(5.3)$ \\
$128(83.7)$ & $25(16.3)$ & & $89.6 \%$ & $1(99.3)$ \\
$10(52.6)$ & $9(47.4)$ & 152 & $3(15.8)$ \\
\hline
\end{tabular}

Even when asset size is included in these models, prediction accuracy does not change significantly. This means that firm size does not play a role in discriminating between companies that have CSR and those that do not.

These findings are close to other business events (e.g., the prediction of bankruptcies, mergers and acquisitions, liquidations, audit opinions) where financial ratios have been used as predictors. This study thus suggests that the proposed model offers an accurate forecast of CSR because prediction accuracy is above $90 \%$, which is much higher than the corresponding rate in the abovementioned business events. Finally, we find that normality in the data sets plays a role in the success of one compared with the other model because the moderate degree of normality led to logit rather than to discriminant analysis.

\section{CONCLUSIONS AND SUGGESTIONS FOR FUTURE RESEARCH}

By applying two widely used models that test the determinants of a dichotomous choice in a scarcely investigated area of research in a specific country, the robustness of these models indicates that CSR can be predicted by a rate higher than $90 \%$ using a logit specification. This rate is much higher than the corresponding rate of other business events. The discriminating factor between the two categories of companies is mainly stock returns, which is a combination of stock prices and dividends. This study used market variables with data on Greek-listed companies. Applying the presented analysis to data on European countries with different financial and economic structures would offer a great challenge for future research.

\section{AUTHOR INFORMATION}

Anastasia G. Maggina, is a Ph.D. holder in Accounting graduated at the Aristotle University of Thessaloniki. I have taught at Greek Universities and American Universities in Greece. I have worked at the Center of Planning and Economic Research (Ministry of National Economy) and as a senior Consultant. I have published in many scholarly Journals and in several Greek newspapers. I have published several books and monographs. I have provided professional services in various Committees and AAA Meetings as well as in various Journals as a reviewer and as member of many Editorial Boards. E-mail: anastasiamaggina@yahoo.gr. Corresponding author.

Professor Angelos A. Tsaklanganos, is a Professor of Accounting at the University of Nicosia, Cyprus and an Emeritus Professor of the Aristotle University of Thessaloniki, Greece. He has a Ph.D. and MBA from New York University, Stern School of Business and has taught at N.Y.U./Stern, Baruch College of the City University of New York, Rutges University, Temple University, Columbia University and Lavern University. His articles appear in 
many scholarly journals. He has written over 20 books in Accounting and Business Administration (in Greek) and was a Consultant for the Ministry of National Economy, the Telephon Co, the Power Co and other businesses. He served as President of the Productivity Center and Board Member in many public and private enterprises. E-mail: tsaklag@gmail.com

\section{REFERENCES}

1. $\quad$ Alexander, J.G. and R.A. Buchholz (1978), "Corporate Social Responsibility and Stock Market Performance", Academy of Management Journal, 21, 3, pp. 479-486

2. Arlow, P. and M. Gannon (1982), "Social Responsiveness, Corporate Structure, and Economic Performance", Academy of Management Review, 7, pp. 235-241

3. Aupperle, K.; A. Carroll and J. Hatfield (1985), "An Empirical Examination of the Relationship Between Corporate Social Responsibility and Profitability”, Academy of Management Journal, 28, pp. 446-463

4. Bowman, E. and M. Haire (1975), “A strategic Posture Towards CSR”, California Management Review, 18,1, pp. $49-58$

5. $\quad$ Bragdon, J.H. and J. Marlin (1972), "Is Pollution Profitable”, Risk Management, 19, 4, pp. 9-18

6. Carrington, J. (1970), "Personnel Executives and Social Responsibility”, Personnel Journal, 49, June, pp. 504-507

7. Cochran P.L. and R.A. Wood (1984), "Corporate Social Responsibility and Financial Performance", Academy of Management Journal, 27, 1, pp. 42-56

8. Cornell, B. and A. Shapiro (1987), "Corporate Stakeholders and Corporate Finance", Financial Management, 16, pp. 5-14

9. Easton, P. and T. Harris (1991), "Earnings as an Explanatory Variable for Returns", Journal of Accounting Research, 29, 1, pp. 19-36

10. European Council (2003), "Council Resolution of 6 February 2003 on Corporate Social Responsibility", Official Journal of the European Union (18-2-2003), C 39/3-2003/C 39/02

11. Heal, G. (2004), "Corporate Social Responsibility - An Economic and Financial Framework", ssrn.com

12. Heslin, P.A. and J.D. Ochoa (2008), "Understanding and Developing Strategic Corporate Social Responsibility", Organizational Dynamics, 27, 2, pp. 125-144

13. Juran, J.M. (1994), "The Upcoming Century of Quality", Annual Quality Congress Proceedings, ASQ, Milwaukee, WI

14. Lin, C.H.; H.L. Yang and D.H. Liou (2009), "The Impact of Corporate Social Responsibility on Financial Performance: Evidence from Business in Taiwan", Technology in Society, 31, pp. 56-63

15. McGuire, J.B.; A. Sundgren and T. Schneeweis (1988), "Corporate Social Responsibility and Firm Financial Performance", Academy of Management Journal, 31, 6, pp. 54-872

16. McWilliams A. and D. Siegel (2000), "Corporate Social Responsibility and Financial Performance: Correlation or Misspecification?”, Strategic Management Journal, 21, 5, p. 603

17. (2001), "Corporate Social Responsibility: A Theory of the Firm Perspective", Academy of Management Review, 26, pp. 117-127

18. Mele, D. (2004), “Corporate Social Responsibility in Spain: An Overview”, ssrn.com

19. MEDA Communication SA (2009), Awareness and Social Behavior Index Report, 2009

20. Morrison Paul, C.J. and D.S. Siegel (2006), "Corporate Social Responsibility and Economic Performance", Journal of Productivity Analysis, 26, 3, pp. 207-211

21. Moskowitz, M.R. (1972), "Choosing Socially Responsible Stocks", Business and Society Review, 1, 1, pp. 71-75

22. Moskowitz, M.R. (1975), "Profiles in Corporate Social Responsibility", Business and Society Review, 13, pp. 29-42

23. Moussavi, F. and D. Evans (1986), “An Attributional Approach in Measuring Corporate Social Performance", Paper Presented at the Academy of Management Meetings, San Diego

24. Nelling, E. and E. Webb (2009), "Corporate Social Responsibility and Financial Performance: the 'Virtuous Circle' Revisited”, Review of Quantitative Finance and Accounting, 32, 2, pp. 197-209

25. Parker, I.R. and H. Eilbirt (1975), "Social Responsibility: The Underlying Factors", Business Horizons, 18, 4, pp. 5-10 
26. Sikka, P. (2010), "Smoke and Mirrors: Corporate Social Responsibility and Tax Avoidance", Accounting Forum, 34, 3-4, pp. 153-168

27. Spicer, B.H. (1978), "Investors, Corporate Social Performance, and Information Disclosure: An Empirical Study", The Accounting Review, 3, pp. 94-111

28. Sturdivant, F.D. and J.L. Ginter (1977), "Corporate Social Responsiveness: Management Attitudes and Economic Performance", California Management Review, 19, 3, pp. 30-39

29. Stroup, M. and R. Newbert (1987), “The Evolution of Social Responsibility”, Business Horizons, 30, pp. $22-24$

30. Tsaklanganos, A. (1974), "Social Problems and Corporate Concern: The Expanded Scope of Responsibility", Akron Business and Economic Review, Winter, 5, 4, pp. 10-15

31. Tsaklanganos, A. (1976), "Change at the Source of Change: Redefining Corporate Objectives", Business and Public Affairs Journal, 3, 1, pp. 33-40

32. Ullmann, A. (1985), "Data in Search of a Theory: A Critical Examination of the Relationships Among Social Performance, Social Disclosure, and Economic Performance", Academy of Management Review, 10, pp. 540-577

33. Vance, S. (1975), “Are Socially Responsible Corporations Good Investment Risks?”, Managerial Review, 64,8, pp. $18-24$

34. Waddock, S.A. and S.B. Graves (1997), "The Corporate Social Performance-Financial Performance Link", Strategic Management Journal, 19, 4, pp. 303-319

35. Zairi M. and J. Peters (2002), "The Impact of Social Responsibility on Business Performance", Managerial Auditing Journal, 17, 4, pp. 174-178

Notes: Excerpt from the "Council Resolution of 6 February 2003 on corporate social responsibility (2003/C 39/02)":

The Council welcomes the Communication from the Commission, including the Commission's view that a strategy to promote CSR should be based on:

- recognition of the voluntary nature of CSR,

- a need for credibility and transparency of CSR practices,

- $\quad$ a focus on activities where Community involvement adds value,

- a balanced and broad approach to CSR, including economic, social and environmental issues as well as consumer interests,

- $\quad$ attention to the specific needs and characteristics of small and medium-sized enterprises (SMEs), and

- $\quad$ support of, and compatibility with, existing internationally agreed instruments.

Emphasizing that CSR is behavior by businesses over and above legal requirements, which should continue to be properly enforced, and that:

- $\quad$ globalization has created new opportunities for enterprises, but it has also increased their organizational complexity; therefore policies on CSR should focus not only on single undertakings, but also on their subsidiaries and subcontractors,

- the debate on CSR must be seen in the wider context of corporate governance and accountability,

- $\quad$ in order to be effective, CSR should be a part of a concerted effort by all those concerned towards meeting shared objectives, including social and civil dialogue in accordance with national law and practice,

- $\quad$ undertakings should address not only the external aspects of CSR, but also the internal aspects such as health and safety at work and management of human resources.

Supporting the intentions of the Commission, in particular to focus its strategy on:

- $\quad$ increasing knowledge about the positive impact of CSR on business and societies in Europe and abroad, in particular in developing countries, 
- $\quad$ developing exchange of experience and good practice on CSR between undertakings, including SMEs, in particular through business organizations and networks,

- $\quad$ promoting the development of CSR management skills,

- facilitating convergence and transparency of CSR practices and tools, which should, inter alia, build on the fundamental ILO Conventions and on the OECD Guidelines for Multinational Enterprises, as minimum common standards of reference,

- $\quad$ integrating CSR into Community policies. 